it necessary to turn to them, ${ }^{1}$ and for this reason, if for no other, it is desirable to place them in their true setting and to mark them off from the earlier Lives of which they are partly imitations.

Caradoc of Llancarvan was, as we have said, a contemporary of Geoffrey of Monmouth, whose Historia Regum Britanniae was written c. I $136 .^{2}$ The Durham MS of the Life of St Gildas was written in 1 I66; and of the Life of St Cungar we have a twelfth-century fragment. These two Lives may have been written at any time between I I 20 and II 50 . The two later Lives were probably composed towards the end of the twelfth century. They give no evidence of acquaintance with the work of Geoffrey of Monmouth, and the Arthurian material which they contain testifies to Welsh tradition before or soon after his time. Our enquiry. therefore may be thought to have a certain literary value apart from its hagiographical interest. I must ask pardon for trespassing in these fields, and daring to write, as Nennus would say, 'quasi garrula avis vel quasi quidam invalidus arbiter' : and I gladly repeat the last words of his Apologia: 'Cedo illı qu plus noverit in ista peritia satis quam ego.'

J. Armitage Robinson.

\title{
IS ECCLESIASTES A TRANSLATION?
}

THE title of this Note is phrased as a query, because the matter is not clear to my mind. But I have had for some time a feeling that the style of Ecclesiastes is, in certain respects, unsatisfactory and disconcerting, and the answer which to me raises the least difficulty and satisfies most of the data is that what we have is not an original but a translation. I cannot offer a demonstration of this, but I venture to hope that my remarks will not be out of place as a suggestion.

- The Book called Ecclesiastes, itself a rendering of the extraordinary Hebrew title Koheleth, is a most original work. Especially is thıs the case if we think of originality as a quality displayed rather in getting to grips with the essentials of a problem than in saying brilliant things about the surface of it. The author, considering the ancient problem of the unequal distribution of what are generally supposed to be the. desirable things of life, passes on to consider the nature of real happiness, real success. He comes to the conclusion that a good deal of what passes for success is in itself worthless, and that the only positive good

${ }^{1}$ See especially the admirable work of R. H. Fletcher in his Arthunan Material in the Chronicles (1906) pp. $105 \mathrm{fr}$.

2 Ibid. p. 45. 
is having a job and liking it $\left(\mathrm{V}_{17}, 18\right)$-as distinct from the evil of having a job which you don't like, in order at some future time and place to have the means to enjoy what you now think you will like when you get it.

But the clear thinking of Ecclesiastes is expressed in a singularly bald . style. The baldness is perceptible in the English Version, but it is far worse in the Hebrew. There is no literary charm in the book due to the use of language ${ }^{1}$ : the undoubted impressiveness of many passages is due to the underlying thought.

Is there any real parallel to this in literature? The strange Greek of the Apocalypse of John is very far from baldness. It has a charm of its own : it is only the schoolmaster who is repelled. Mark is written not 'in order', in an unliterary, unconventional style, but it is full of striking words and phrases. The Fourth Gospel might possibly be described as bald in style, but it is quite correct.

This brings me to the linguistic character of Ecclesiastes. Can the style of Ecclesiastes be described as correct or natural ? It seems to me neither. It seems to me to have the awkward stiffness of a translation. If it be a translation, it is naturally a translation from the Aramaic. The object of this Note is to ask whether the view that Ecclesiastes is a translation from the Aramaic does not solve many of the linguistic problems offered by the book.

The Aramaic influence in Ecclesiastes is of course evident, but usually it is explained to be due to 'an author who thought in Aramaic, and translated the Aramaic idiom, part by part, into unidiomatic Hebrew' (Driver Lit. O. T., ed. 1894, p. 445 note 2). But if Aramaic be the language of the writer, why should he express his thoughts in Hebrew at all, except on the hypothesis that he aimed at canonicity? Or, at least, that he aimed at writing something in the general style of ancient Hebrew literature. This surely is not the case. He does not make any claim to 'inspiration'. Joel seems to be an imitation of the old, pre-exilic prophetic style; many of the Psalms are no doubt quite late, so is Esther, so is Chronicles. But these books, though their lateness is evident to an attentive student, are not altogether incongruous with the older books. Daniel is the nearest parallel to Ecclesiastes, and part of Daniel is extant only in Aramaic, while the rest is itself possibly a translation. But even if the Hebrew parts of Daniel were originally written in Hebrew, there is an obvious reason, for Daniel professes to be prophecy and revelation, while Ecclesiastes makes no claim at all of that sort. Is it not more likely that the thoughts of the unconventional sceptic were put into form in the language of everyday?

1 Except the use of mishpat! ( = 'how') in viii $5,6:$ possibly this is a quoted proverb. 
I have begun with these general considerations, because they seem to me fundamental. They seem to me to give the reason for declaring the question open. I now come to one or two definite instances, where it seems to me that the Hebrew text as we have it is rather the work of a not always skilful translator than that of 'an author who thought in Aramaic ' and wrote in something else.

(a) Eccl. vii $\mathrm{r}^{\mathrm{b}}\left(\mathrm{r} 5^{\mathrm{b}}\right)$.

'God hath even made the one side by side with the other to the end that man should not find out any thing that shall be after him.'

I quote the R.V., but I do not find it convincing, either as a sentiment, or as a strict rendering of the Hebrew, which ends with the words על דברת שלא ימצא הארם אחריו מאומה

lit. 'for the reason that no man should find after him aught'.

The question arises to whom 'him' refers - to man or to God? The English Version and a good many modern expositors refer it to man, but

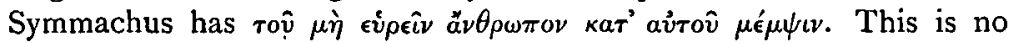
paraphrase, but a literal translation of what the sentence would mean if we treated it as Syriac. To find a thing after so-and-so means in Syriac to find him guilty of or responsıble for it. A good example is Lk. xxiii

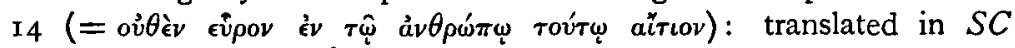
cidu duare $<$ (literally: 'Nothing have I found after him '): other instances are Dan. vi 4, John xix 4, Acts xxviii I 8 (all syr. vg.), and Lk. xxiii i $5 S C$.

According to this view, therefore, we should translate 'God has made one thing against the other in such a way that no man should find any occasion of complaint against Him '.

This seems to me quite in accordance with the thought of Ecclesiastes, but I doubt if it be real Hebrew. I think it is an over-literal translationfrom an Aramaic original made by a translator who referred ' after him 'to man.

(b) Eccl. iv $\mathrm{I}_{5} \mathrm{f}$.

'I saw all the living which walk under the sun, that they were with the youth, the second, that stood up in his stead. There was no end to all the people, even of all them over whom he was: yet they that come after shall not rejoice in him.'

This is R.V., which hardly differs from A.V. If the Bible were more read, instead of being talked about, I fancy we should not hear quite so much about 'the noble English of our incomparable Version'. To such a passage as I have transcribed the only appropriate remark appears to me to be the words which immediately follow-'surely this also is Vanity!'

On looking at the passage, however, one sees that it is a general remark about all men, and further that there seems to be some contrast intended between those that come after and their predecessors, a contrast 
between some one and the youth who will be his successor. The decisive word is evidently that translated 'the second'. Second to whom? to his elder brother, or to his father?

The Hebrew is השי, which of itself rather suggests a second son, as it does in English. But may it not be a mere rendering of the Aramaic tinyana (Syr. trayānā)? This word in Aramaic often imnlies the notion of 'second in command'. In the Hymn of the Soul the Brother of the hero, i. e. the exalted Jesus, is called the trayann $\bar{a}$ of the King of Kings, and in the Targums to Jerem. xvii 15 and Zech. xiii 7 the tinyanayya are 'persons of the second rank'.

With this clue we can make sense of the passage. 'The living' are the present generation, now in power and activity. 'The youth' is the second in command, destined in due course to supplant the present generation. There is no limit to human numbers, counting all the successive generations, but the latest generation have no cause for satisfaction (' rejoice thereat', not 'rejoice in him'), for all 's a bubble!

'I saw all the living under the sun going along with the youthful generation, now occupying the second place, who will one day supplant their elders. There is no end to all the people, those that were before them ; yet let the last comers not rejoice thereat, for that also is Vanity.'

This makes sense, but is it Hebrew? I doubt it, except it be regarded as translation Hebrew.

(c) The transmitted text of Ecclesiastes seems to have suffered here and there, but I venture to ask whether some of the passages which, as they stand, make no sense, do not look rather like the efforts of a translator who does not quite understand what is before him. Examples are iv $\mathbf{~} 4_{4} \mathrm{~b}$ (נולר), v 6, xii I I b. 1 do not include vi 8 b in this list, for it seems to me that the incoherence is due to corruption. The advantage of the wise man over the fool, seeing that their fates (according to our author) are so much alike, should consist in some saving or excepting clause: read, therefore, מה לעני for מבלער, and translate 'What advantage hath the wise man over the fool, except that he knows how to walk (i.e. to behave) before his contemporaries?'

In the difficult passage Eccl. viii ro also I feel it is impossible to make sense without emendation, and I take this opportunity of suggesting קרבים (or מקרבים (or) מקרבים be preferred the word will have the technical sense of offering a sacrifice, if קרבים it will have the more general meaning of coming near to God in the Temple: in etther case, therefore, it has the connotation of 'going to church'.

1 In this last verse there is surely some corruption: 'from one shepherd' (מרעה אחר) is nonsense. The context suggests' that by means of the lips the mind of one is imparted to others, i.e. the phrase should end with מרע .מרע האחר ('mind', ' intelligence') occurs in Eccl. $x 20$, and is 'given' in 2 Chr. i ro, 12. 
With this trifling change, and reading with Aquila, Symmachus, and Theodotion, and practically the 'LXX', וישתמחו" the sense is: 'And further I have seen wicked men at worship, and they who have done so come in and go off on their ways from the Holy Place and boast of it-this also is Vanity !'

If Ecclesiastes be a translation it is not out of place to suggest that the mysterious שואק

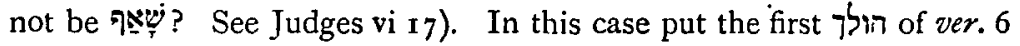
into ver. 5 and translate

'And the Sun rises and the Sun sets, and to its place where also it rises does it go. To the South and round to the North, round and - round goes the Wind. ...'

As has been pointed out by Siegfried and others, there is elsewhere in O.T. no trace of the idea that the Sun goes on his course with fatigue or effort, so that an unexplained allusion to the Sun 'panting' is really a difficulty.

(d) Finally, all the long lists of Aramaic words and constructions, to be found in Siegfried or any other good Commentary on Ecclesiastes, will on this hypothesis receive their due explanation. No doubt 'Aramaisms' did invade the later Hebrew style, but that was when it was really a dead language. The later we put the 'Maccabaean' Psalms, the Books of Chronicles, Esther, Ruth, \&c., the more that we incline to postulate a Hebrew original for Juhilees or the Testaments of the XII Patriarchs, the harder is it to believe that Ecclesiastes was composed in the crabbed and unnatural lingo in which we read it in our Hebrew Bibles. It is better as Hebrew than some parts of the Greek Bible are as Greek, but I do not think it any better than that. I find it difficult to believe that so acute and careful a thinker would have employed such a vehicle for his thought, and therefore I welcome the evidence here brought forward, which seems to me to suggest that what we have of the Preacher is a translation from a lost Aramaic original.

F. C. Burkitt.

\section{Additional Note on the physical meaning of 'Vanity'.}

The word הכetel, translated 'vanity' in the English Bible, is a key-word in Ecclesiastes. We are not likely to apprehend fully the thought of the writer in applying the word to human life and effort, until we know the real physical meaning. It is commonly said to mean 'breath' or 'a puff of wind'. When, however, we look for the proof of this statement we find it is an inference from Isaiah lvii 13 , where it seems to stand in parallelism to ria $a$. Generally it is used meta- 